\title{
National Energy Policies and the Electricity Sector in Malaysia
}

\author{
Thahirah Syed Jalal \\ Electronics and Communication Engineering Department, \\ Universiti Tenaga Nasional (UNITEN) \\ Selangor, Malaysia \\ thahirah@uniten.edu.my
}

\author{
Pat Bodger \\ Department of Electrical \& Computer Engineering, \\ University of Canterbury, \\ Christchurch, New Zealand \\ pat.bodger@canterbury.ac.nz
}

\begin{abstract}
Since its independence in 1957, Malaysia has gone a long way towards developing its economy and infrastructures. As one of the fast growing developing nations, its world renowned infrastructures include the Petronas Twin Towers, the SMART tunnel and the Bakun hydro dam. A key component that enables this growth is its secure, affordable and reliable electricity sector. Even though the initial electricity facilities here were constructed by the British during colonization, Malaysia continued to nurture its development and improve its reliability through her national policies, to ensure that it continued to support her growth and prowess. The main national policy pertaining to the electricity sector in Malaysia is the National Energy Policy. It was formulated in 1979 to ensure efficient, secure and environmentally sustainable supplies of energy, including electricity. Later, other policies were also formulated to address arising issues and concerns in the energy sector. Among them were the National Depletion Policy, the Four Fuel Diversification Policy and the Fifth Fuel Policy. This paper reviews and discusses their implementation and various impacts on the electricity sector in Malaysia.
\end{abstract}

Keywords- National energy policy, electricity supply industry, energy resources, renewable energy, energy efficiency

\section{INTRODUCTION}

The electricity sector in Malaysia has grown much in the last sixty years. As shown in Figure 1, in 1949, the electric energy sold was only $141.3 \mathrm{GWh}$ [1] whereas by 2007 , it had grown to more than $89,000 \mathrm{GWh}$ [2]. This rapid growth has been hand in hand with the nation's economic growth, especially within the industrial and manufacturing sectors.
Figure 1. Electric energy sales in Malaysia between 1949 and 2007 [1-3]

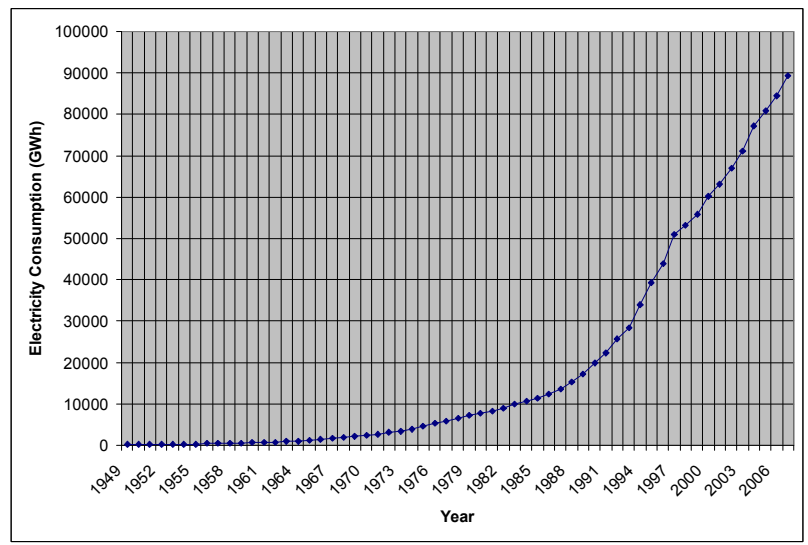

The electricity supply industry is vertically integrated with generally a monopolistic nature, where a utility company handles all the generation, transmission and distribution of electricity in a region. The main utility companies are Tenaga Nasional Berhad (TNB) [4], Sarawak Electricity Supply Company (SESCO) [5] and Sabah Electricity Limited (SESB), each covering the region of the Peninsula Malaysia, Sarawak and Sabah respectively. Each company initially started under the British rule before the nation's independence and has remained till today. Since 1998, SESB became one of the subsidiaries of TNB. In all three regions, there are also independent power producers (IPPs) supplying some portion of the electricity supply to the utility companies to transmit to the consumers.

The sector is governed by several institutions, each with their own functions and areas of jurisdiction, as shown in Table I. 
TABLE I. THE KEY INSTITUTIONS IN THE ENERGY SECTOR [6-9]

\begin{tabular}{|l|l|}
\hline \multicolumn{1}{|c|}{ Institution } & \multicolumn{1}{|c|}{ Area of jurisdiction } \\
\hline $\begin{array}{l}\text { Economic } \\
\text { Planning Unit } \\
\text { (EPU) }\end{array}$ & $\begin{array}{l}\text { Responsible for formulating, regulating and } \\
\text { implementing policies, regulations, legislations, } \\
\text { programmes and projects to improve the economy } \\
\text { and also coordinate functions of other energy related } \\
\text { institutional bodies responsible for a specific sector. }\end{array}$ \\
\hline $\begin{array}{l}\text { Ministry of } \\
\text { Energy, Green } \\
\text { Technology Water }\end{array}$ & $\begin{array}{l}\text { Policy formulator and service regulator for the } \\
\text { energy, green technology and water sectors; facilitate } \\
\text { and regulate the growth of these sectors }\end{array}$ \\
\hline $\begin{array}{l}\text { The Energy } \\
\text { Commission } \\
\text { (EC) }\end{array}$ & $\begin{array}{l}\text { Handles all the regulatory functions of the Ministry } \\
\text { of Energy }\end{array}$ \\
\hline
\end{tabular}

Besides the institutions mentioned in Table I, the Malaysia Energy Centre (Pusat Tenaga Malaysia, PTM) is another important institution that coordinates various activities, specifically planning and technological research, development and demonstration in the energy sector [10].

All the three main electricity utilities in Malaysia are government linked companies (with the government as the main shareholder) and they are heavily regulated by the institutions mentioned in Table I. Hence the electricity sector is very much influenced by government policies.

Section II briefly discusses the policies that are in place. Section III then describes the policies' implementation and Section IV which discusses the possible future directions of the sector. This paper is concluded in Section V.

\section{BRIEF HistORY OF MALAYSIA's NATIONAL POLICIES DEVELOPMENT}

The energy policies in Malaysia are formulated by the Energy Section of the EPU under the Prime Minister's Department. It is renewed every five years as part of the Five Year Malaysia Plan.

The very first major policy formulated concerning the energy sector in Malaysia was in 1974. Under the Petroleum Development Act 1974, Petroliam Nasional Berhad (Petronas) was established as the national oil company and vested it with the responsibility for exploration, development, refining, processing, manufacturing, marketing and distribution of petroleum products [9]. Next in 1975, the National Petroleum Policy (1975) was formulated in the Third Malaysia Plan (1976-1980) with the objective of bringing about efficient utilization of the resource for industrial development, as well ensuring that the nation exercises majority control in the management and operation of the industry. Its aim was to guide and regulate the fast growing petroleum industry in Malaysia where massive production was encountered with an average growth rate of about $40.5 \%$ per annum between 1970 and 1975 [9]. These two policies do not directly govern the electricity sector and hence will not be discussed in great detail in this paper. They are mentioned because they affect the way the fuel resources are supplied to the electricity sector, where the local resources are utilized as much as possible for power generation to support the local petroleum industry.

An overall energy policy was formulated in 1979 (National Energy Policy 1979) with broad guidelines on long term energy objectives and strategies to ensure efficient, secure and environmentally sustainable supplies of energy. This is the main policy that governs the energy sector in Malaysia. Other policies were later introduced to support its objectives and implementations.

The National Depletion Policy 1980 was introduced to safeguard the exploitation of natural oil reserves because of the rapid increase in the production of crude oil. As a complement, the Four Fuel Diversification Policy 1981 was then designed to prevent over-dependence on oil as the main energy resource. Its aim was to ensure reliability and security of the energy supply by focusing on four primary energy resources: oil, gas, hydropower and coal [9].

During the Seventh Plan period (1996-2000), for the electricity sector, the main thrust was ensuring adequacy of generating capacity as well as expanding and upgrading the transmission and distribution infrastructure [11]. In 2000, the Four Fuel Policy was amended to become the Fifth Fuel Policy (Eighth Malaysia Plan 2001-2005) where renewable energy (RE) was announced as the fifth fuel in the energy supply mix. Energy efficiency was also encouraged to prevent Malaysia from becoming a net energy importer which will affect her economic growth [12].

The Ninth Plan strengthens the initiatives for energy efficiency and renewable energy put forth in the Eighth Malaysia Plan that focused on better utilisation of energy resources [13]. An emphasis to further reduce the dependency on petroleum provides for more efforts to integrate alternative fuels. Various tax exemptions were introduced for energy efficiency implementers and renewable energy generators. The updates on the energy policies are summarized in Figure 2.

Figure 2. The national energy policies that directly governs the electricity sector

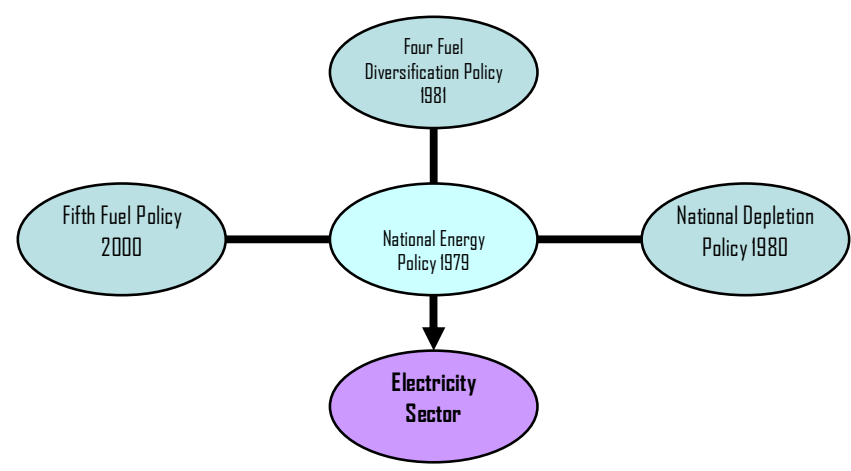

\section{POLICIES IMPLEMENTATION}

In this section, the implementation of all the policies is discussed under the implementation of the National Energy Policy 1979. Since the three policies were formulated to 
complement it, it is difficult to describe their implementation separately.

The National Energy Policy 1979 has identified three objectives, which are:

- $\quad$ supply,

- utilization and

- environmental

\section{A. The supply objective}

The Supply Objective was aimed to ensure the provision of adequate, secure, and cost-effective energy supplies through developing indigenous non-renewable and renewable energy resources using least cost options and diversification of supply sources both from within and outside Malaysia [9]. When the national depletion policy was introduced in 1980, production control on major oil fields was implemented. The major oil fields of over 400 million barrels of oil initially in place (OIIP) restricted their production to 1.75 per cent of OIIP. However, in 1985 , the ceiling was revised to 3 per cent in view of the fact that 1.75 per cent was on the conservative side. As a result of this policy, the total production of crude oil is currently limited to about 650,000 barrels per day. As such, at the current production rate, proven oil reserves are expected to last another 16 years [8].

In 1981, when the Government adopted the four-fuel strategy, the strategy was to utilize non-oil domestic energy resources, to increase the country's self-reliance with respect to energy supply and savings in foreign exchange [14]. It aimed for a supply mix of oil, gas, hydropower and coal in energy use. As much as possible, local resources of these fuels would be used to enhance security of supply. The electricity sector has shown the greatest achievement in terms of the four fuel policy where the dependence upon fuel oil has been reduced. This can be observed from the electricity generation fuel mix trends from 1985 to 2005, as shown in Figure 3.

Figure 3. Electricity generation fuel mix in Malaysia from 1985 to 2005 [Malaysia Plan 5- 8]

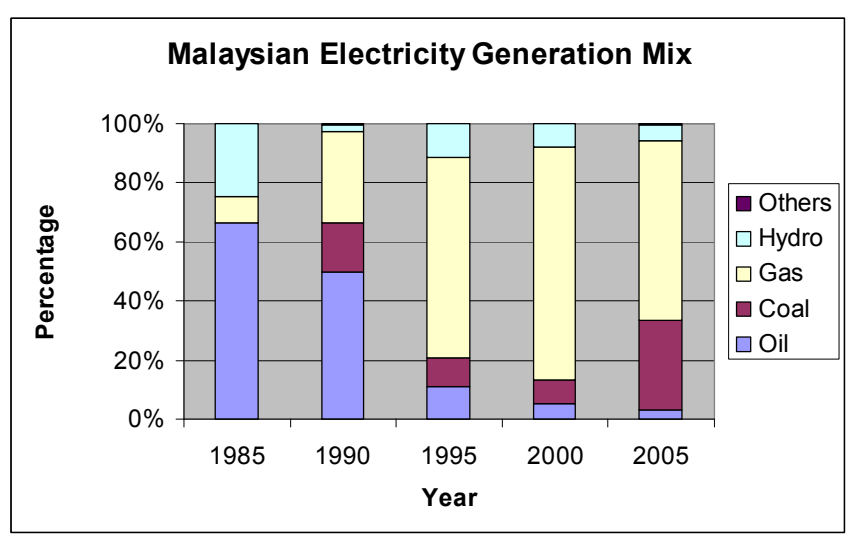

From Figure 3, the high dependence on oil in 1985 has been significantly reduced throughout the years, substituted by natural gas that is found in abundance in Malaysia. This has been further enhanced when the IPPs came into the electricity sector in 1993. The IPPs have a higher tendency to build gas power plants due to quick plant up time, lower capital cost and easy operation. The sector then became too dependent on gas and the national depletion policy was later extended from crude oil to include the natural gas reserves. An upper limit of 2,000 million standard cubic feet per day (mscfd) has been imposed in Peninsular Malaysia. At the current rate of production, known natural gas reserves are expected to last for about 70 years [8].

The government later strived to reduce dependence on gas. Despite environmental and foreign exchange implications (coal is imported from Indonesia and Australia), several coal power plants were planned and built including a 3x700MW plant in Manjung by TNB Janamanjung which was commissioned in 2003. The government is also planning to utilize nuclear power as an electricity source by 2023 , in view of the depletion of coal and natural gas. In 2008, the Energy, Water and Communications Minister, Datuk Shaziman Abu Mansor said, "The Government was left with no choice but to use nuclear energy as it was the better alternative". He also said that the exceptionally-high prices of gas and coal were another reason the Government had to start looking for alternatives [15].

When the Fifth Fuel Policy was introduced in 2001, renewable energy was targeted to be a significant contributor to the country's national grid with the generation mix of $5 \%$ of the total electricity demand by 2005 (about 500MW) [6, 16]. With this aim, the Small Renewable Energy Program (SREP) was launched in May 2001. Plants under the SREP projects can sell up to a maximum of $10 \mathrm{MW}$ of electricity to the National Grid.

By the end of May 2003, a total of 48 projects were approved with a grid connected capacity of $267.3 \mathrm{MW}$. Of these, 28 were biomass projects, 16 mini-hydro and four landfill gas. Apart from the SREP projects, the non-grid connected facilities of palm oil mills produced for their own consumption about $1,065 \mathrm{GWh}$ or 1.3 per cent of the total electricity generated in 2003. To encourage the utilisation of $\mathrm{RE}$, the 2001 Budget provided fiscal incentives for companies which utilised biomass as a source of energy. These incentives were extended for another three years until December 2005 [17]. However, within the five years duration, only two SREP projects were successfully implemented [16], which were:

- $\quad$ TSH Bioenergy project in Tawau (10MW) - the first grid connected biomass power plant in Malaysia using the fuel mixture of empty fruit bunch $(70 \%)$, fiber $(20 \%)$ and dry shell $(10 \%)$ from palm oil wastes

- Jana Landfill in Puchong (2MW) - the first landfill gas power plant in Malaysia

The renewable resources that were identified in Malaysia can be generally categorized as biomass (including biogas), solar and hydro for energy generation. Figure 4 shows the details of the identified resources, based on their availability and utilization prospects. 
Figure 4. Identified renewable energy resources in Malaysia [16]

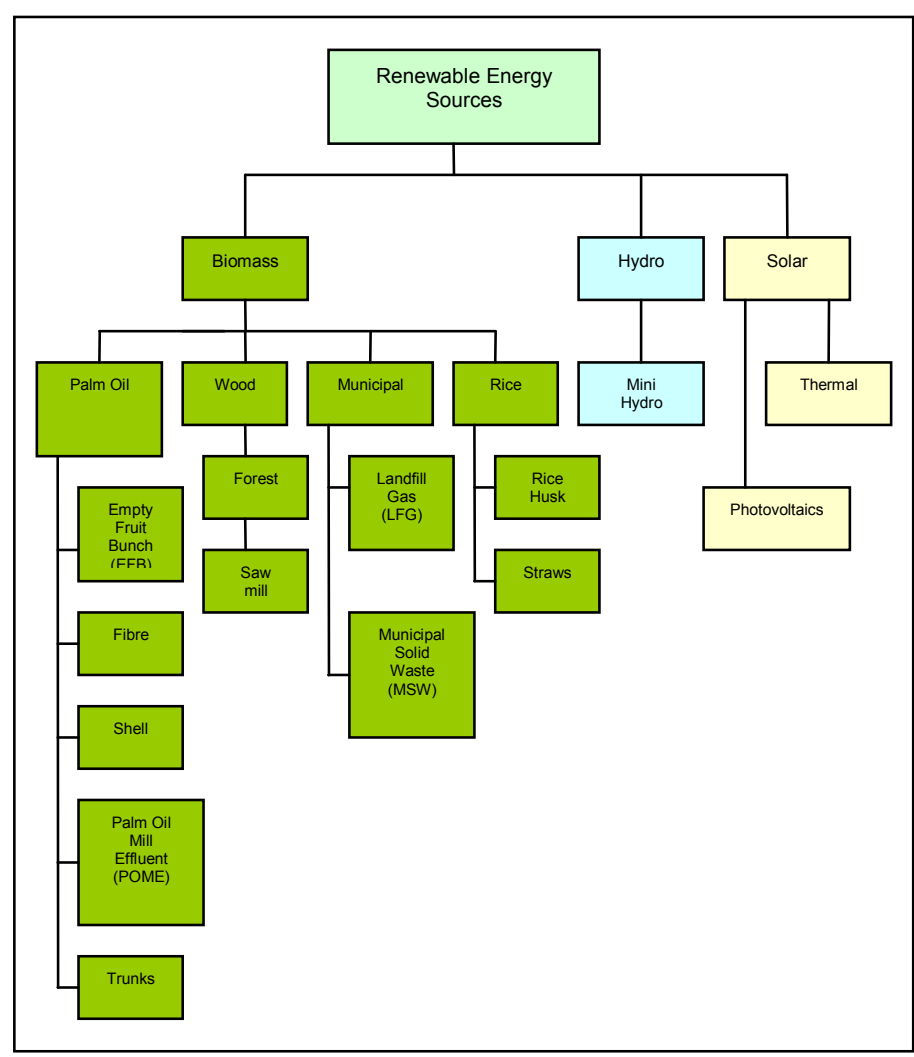

The target of $5 \%$ of RE penetration was revised to be $350 \mathrm{MW}$ in the Ninth Malaysia Plan. Out of 350MW, 245MW was aimed to be achieved from biomass (193MW from palm oil wastes, 35MW from MSW, 7MW from LFG, 10MW from rice husk) whereas the remaining $105 \mathrm{MW}$ was from mini hydro.

To encourage biomass utilization in Malaysia, the Biomass Generation \& Co-generation in the Malaysia Palm Oil Mill (BioGen) was launched in October 2002. This is a United Nations Development Programme (UNDP) and the Global Environmental Facility (GEF) programme for the development of cogeneration technology. Its application related to renewable energy resources using POME and also to reduce the growth rate of greenhouse gas (GHG) emissions from fossil fuel fired combustion processes [18]. The detailed components of the BioGen programme are provided in Table II.

\begin{tabular}{|c|c|}
\hline Components & Details \\
\hline $\begin{array}{l}\text { Component } 1: \\
\text { Biomass } \\
\text { Information } \\
\text { Services } \quad \& \\
\text { Awareness } \\
\text { Enhancement } \\
\text { Program }\end{array}$ & $\begin{array}{l}\text { Address the information barriers that hinder the } \\
\text { development and implementation of biomass- } \\
\text { based grid connected power generation/CHP in } \\
\text { relevant industries such as the palm oil industry. It } \\
\text { involves the implementation of capacity building } \\
\text { activities and information dissemination services } \\
\text { to ensure information on biomass energy } \\
\text { technology is widely and freely available. }\end{array}$ \\
\hline $\begin{array}{l}\text { Component } 2: \\
\text { Biomass Policy } \\
\text { Study and } \\
\text { Institutional } \\
\text { Capacity } \\
\text { Building }\end{array}$ & $\begin{array}{l}\text { Build on the existing policy studies regarding } \\
\text { renewable energy as the "fifth fuel" for power } \\
\text { generation, and aims to remove the institutional } \\
\text { and price-related barriers to the development and } \\
\text { implementation of biomass-based power } \\
\text { generation and CHP. }\end{array}$ \\
\hline $\begin{array}{l}\text { Component } 3: \\
\text { Biomass } \\
\text { Initiatives } \\
\text { Financing } \\
\text { Assistance } \\
\text { Program }\end{array}$ & $\begin{array}{l}\text { Encourage the government, private sector and the } \\
\text { financial communities to provide financial } \\
\text { assistance to the development and implementation } \\
\text { of biomass-based power generation/cogeneration } \\
\text { projects. }\end{array}$ \\
\hline $\begin{array}{l}\text { Component } 4: \\
\text { Biomass-Based } \\
\text { Power } \\
\text { Generation } \\
\text { Demonstration }\end{array}$ & $\begin{array}{l}\text { Demonstration sites are selected to participate in } \\
\text { the BioGen technology demonstration projects. }\end{array}$ \\
\hline $\begin{array}{l}\text { Component 5: } \\
\text { Biomass Energy } \\
\text { Technology } \\
\text { Development } \\
\text { Program }\end{array}$ & $\begin{array}{l}\text { Train and provide support to local plant engineers } \\
\text { and operators for plant optimization and efficiency }\end{array}$ \\
\hline
\end{tabular}

From the programme, it is expected that a conducive environment is created in Malaysia for biomass and cogeneration from palm oil mills. There are also two full scale models that would be implemented in Malaysia [18]:

- $\quad 10 \mathrm{MW}$ biogas power plant in Serting

- $13 \mathrm{MW}$ biomass power plant in Bahau (utilizing EFB)

As for hydro as an energy resource, by 2007 there were already 2,091MW and 29MW of hydro and mini hydropower facilities in Malaysia. They constituted $9.6 \%$ and $0.1 \%$ of the installed capacity respectively [2]. The $2400 \mathrm{MW}$ Bakun power plant is expected to be commissioned by 2011. The hydroelectric potential in Malaysia is very significant. According to the national energy balance 2001, the hydroelectric potential amounts to $29,000 \mathrm{MW}$ (of which 2/3 is in Sarawak). In comparison, the installed central electricity generating capacity in 2007 is $21,815 \mathrm{MW}$ [2]. Other hydroelectric projects that have been identified are [19]: 
Peninsular Malaysia:

- Nenggiri (450MW)

- $\quad$ Lebir (272MW)

- Galas (108MW)

- Ulu Terengganu (516MW)

- Tekai (156MW)

- Telom Dam (91MW)

- $\operatorname{Maran}$ (109MW)

Sarawak:

- $\quad$ Murum (900MW)

- Baleh (950MW)

- $\quad$ Pelagus (770MW)

Sabah:

\section{- $\quad$ Liwagu (164MW)}

If all these identified hydro projects are implemented, they will have a profound effect on the generation mix in Malaysia. However, problems related to land-use, socio-economics, and environment impact makes it questionable whether all of this potential can be harvested [20].

Another project also funded by UNDP-GEF is the Malaysian Building Integrated Photovoltaics (MBIPV), launched in May 2005. It is aimed to increase the utilization of BIPV in Malaysia [21]. The programme components are described in Table III.

\section{TABLE III. THE MBIPV PROGRAMME COMPONENTS [21]}

\begin{tabular}{|c|c|}
\hline Components & Details \\
\hline $\begin{array}{l}\text { Component } 1 \text { : } \\
\text { BIPV } \\
\text { information } \\
\text { services, } \\
\text { awareness and } \\
\text { capacity building } \\
\text { program }\end{array}$ & $\begin{array}{l}\text { Enhance the level of understanding and awareness } \\
\text { for the public and policy makers to understand the } \\
\text { technology, aware of its true benefits and } \\
\text { ecological significance; provide training for } \\
\text { installation contractors }\end{array}$ \\
\hline $\begin{array}{l}\text { Component 2: } \\
\text { BIPV market } \\
\text { enhancement and } \\
\text { infrastructure } \\
\text { development } \\
\text { program }\end{array}$ & $\begin{array}{l}\text { Implement four showcases on selected newly } \\
\text { constructed premises which are a government } \\
\text { building, a commercial building, a highly visible } \\
\text { public building and a residence with a total } \\
\text { capacity of } 100 \mathrm{kWp} \text { to provide key references on } \\
\text { the value-added of BIPV technology integrated } \\
\text { into four different building envelopes; } \\
\text { Implement Suria } 1000 \text { programme where } \\
1000 \mathrm{kWp} \text { will be subsidized and installed over a } 4 \\
\text { year period at residential or commercial buildings } \\
\text { (based on successful biddings by members of the } \\
\text { public). }\end{array}$ \\
\hline $\begin{array}{l}\text { Component } 3 \text { : } \\
\text { BIPV policies } \\
\text { and financing } \\
\text { mechanism } \\
\text { program }\end{array}$ & $\begin{array}{l}\text { Enhance the capacity of policy makers to develop } \\
\text { policies conducive for BIPV for the Tenth } \\
\text { Malaysia Plan }\end{array}$ \\
\hline $\begin{array}{l}\text { Component 4: } \\
\text { BIPV industry } \\
\text { development and } \\
\text { R\&D } \\
\text { enhancement } \\
\text { program }\end{array}$ & $\begin{array}{l}\text { Enhance R\&D activities on product development, } \\
\text { provide technical assistance to improve the testing } \\
\text { facility on quality products and to increase the } \\
\text { involvement of the industry }\end{array}$ \\
\hline
\end{tabular}

The MBIPV programme is still ongoing and if successful, will provide installed capacity of $1.5 \mathrm{MWp}$ of BIPV in Malaysia by the year 2010. It also aims to reduce the current BIPV cost by about $20 \%$ by the year 2010 . It may also provide inputs for policy makers to incorporate in the next Malaysia plan that will further encourage the utilization of BIPV in Malaysia.

Besides these programmes, Malaysia has commissioned its first refuse-derived fuel (RDF) power plant in June 2009. The plant, located in Semenyih, is capable of converting 1000 tonnes of MSW per day into RDF and utilizing it as fuel to generate up to $5 \mathrm{MW}$ of electricity.

\section{B. The utilization objective}

The early stage of the utilization objective was to focus on providing electricity to as many residents as possible. This was implemented through the Rural Electrification Programme where budgets were allocated in each Malaysia Plan for electrification of isolated places. Previously, the government also used the utility companies - National Electricity Board (NEB) (TNB prior to privatization), SESB and SESCO - to bear $50 \%$ of the capital cost of rural electrification programmes. When they were privatized in the 1990s and more IPPs came into picture sfrom 1997, the funds were obtained through the Malaysian Electricity Supply Industry Trust Account (MESITA), where each electricity company would channel a percentage of its profits to the account for projects of national interest. The programme has contributed to electrification improvements in Malaysia as shown in Figure 5. 
Figure 5. Rural Electrification Coverage from 1990-2005 [Malaysia Plan 58]

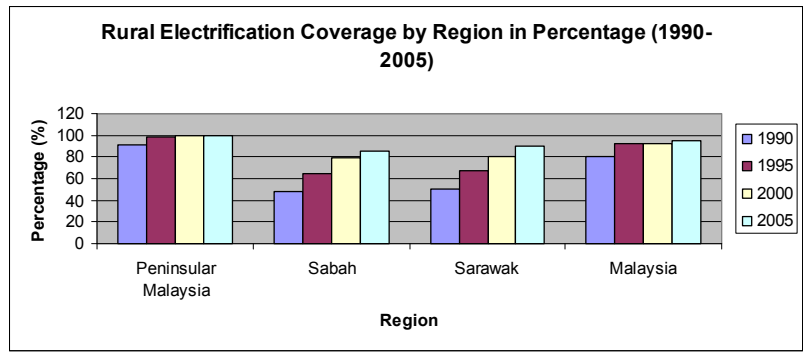

The electricity supply has also improved where the number of interruption incidences has been drastically reduced (see Figure 6).

Figure 6. The electricity interruption incidences between 1995 to 2005 [12, 13]

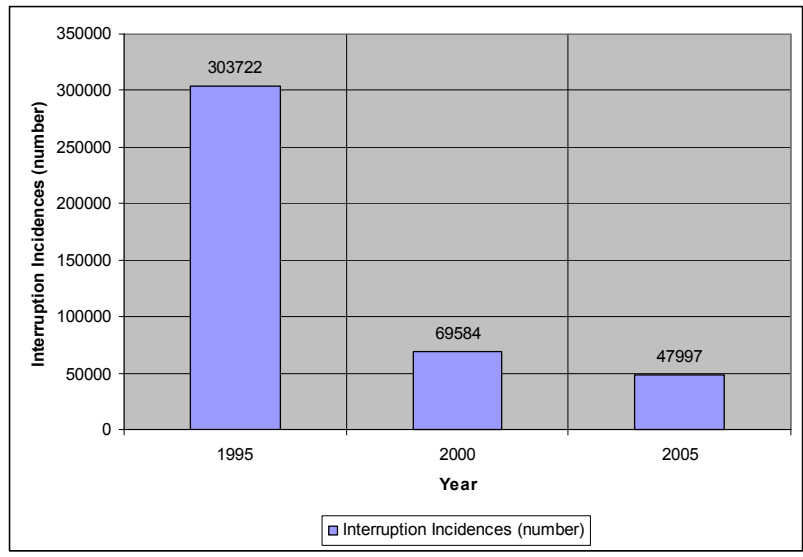

This objective was aimed to promote the efficient utilization of energy and to discourage wasteful and nonproductive patterns of energy consumption. The Government's primary approach to realize this objective is to rely heavily on the energy industry and consumers to exercise efficiency in energy production, transportation, conversion, utilization and consumption through the implementation of awareness programmes. Demand side management initiatives by the utilities, particularly through tariff incentives, have had some impact on efficient utilization and consumption. Co-generations is also encouraged to promote an efficient method for generating heat energy and electricity from single energy sources.

The government believes that to enhance the level of achievement of the Utilisation Objective, the market approach needs to be supplemented by the regulatory approach [8]. In January 2009, the energy efficiency regulation where large power consumers (receiving total electrical energy equal to or exceeding $3 \mathrm{GWh}$ in any period not exceeding six consecutive months) made it compulsory to appoint energy managers and report their consumption regularly to the EC [7]. The main tasks of the energy managers are:

to audit and analyse the total electrical energy consumption
$>$ to advise consumers on developing and implementing measures to ensure efficient management of electrical energy at the installation; and

to monitor effective implementation of the measures referred

Several industrial energy efficiency initiatives are outlined including various tax exemption provisions, energy auditing programmes, energy service companies support programmes and technology demonstration programmes. Energy efficient technologies usually come with a high price tag, and industries are often reluctant to invest in activities that do not have visible benefits to the productivity or profit levels. Besides, factories tend not to prioritise energy efficiency because of the relatively low price of energy in Malaysia.

A notable programme is the Malaysian Industrial Energy Efficiency Improvement Project (MIEEIP), conducted between 2001 and 2007. It is also another UNDP and GEF funded programme. The objective of the MIEEIP is to create a sustainable and conducive environment for energy efficient industries in Malaysia. It was implemented in eight components as shown in Table IV. 
TABLE IV. ThE MIEEIP PROGRAMME COMPONENTS [PTM, 2009]

\begin{tabular}{|c|c|}
\hline Components & Details \\
\hline $\begin{array}{l}\text { Component } 1: \\
\text { Energy-use } \\
\text { Benchmarking }\end{array}$ & $\begin{array}{l}\text { Assist industries to detect their energy inefficiencies by } \\
\text { measuring and comparing their energy intensity at } \\
\text { process level and overall company level against peers } \\
\text { or industries. }\end{array}$ \\
\hline $\begin{array}{l}\text { Component } \\
\text { Energy Audit }\end{array}$ & $\begin{array}{l}\text { Free energy audits are performed at selected industries } \\
\text { to identify how energy is being used in the form of } \\
\text { electricity, gas, oil or steam. The potential for energy } \\
\text { savings are then identified and recommended. }\end{array}$ \\
\hline $\begin{array}{l}\text { Component } 3: \\
\text { Energy Rating }\end{array}$ & $\begin{array}{l}\text { Promote the use of high efficiency motors by adopting } \\
\text { the European Committee of Manufacturers of EU } \\
\text { Electrical Machinery and Power Electronics (European } \\
\text { CEMEP) scheme as the basis for the Malaysian } \\
\text { standard for motors. }\end{array}$ \\
\hline $\begin{array}{l}\text { Component } 4: \\
\text { Energy Efficiency } \\
\text { Promotion }\end{array}$ & $\begin{array}{l}\text { Disseminate information on energy efficient practices } \\
\text { and technology applications to the industries through } \\
\text { the publication of a quarterly newsletter. }\end{array}$ \\
\hline $\begin{array}{l}\text { Component } 5: \\
\text { ESCOs Support }\end{array}$ & $\begin{array}{l}\text { Provide workshops, seminars and training sessions on } \\
\text { business plans, financing, energy engineering and } \\
\text { design tools and energy auditing to build the capacity of } \\
\text { local energy service companies (ESCO). }\end{array}$ \\
\hline $\begin{array}{l}\text { Component 6: } \\
\text { Energy Efficient } \\
\text { Technology } \\
\text { Demonstration }\end{array}$ & $\begin{array}{l}\text { Seven companies have been selected to participate in } \\
\text { the MIEEIP energy efficient technology demonstration } \\
\text { projects, these factories are mainly from the } 54 \text { MIEEIP } \\
\text { audited sites. }\end{array}$ \\
\hline $\begin{array}{l}\text { Component 7: } \\
\text { Local Energy } \\
\text { Efficient } \\
\text { Equipment } \\
\text { Manufacturing } \\
\text { Support }\end{array}$ & $\begin{array}{l}\text { Train and provide support to local equipment } \\
\text { manufacturers on high efficiency designs and } \\
\text { production technologies. }\end{array}$ \\
\hline $\begin{array}{l}\text { Component } 8: \\
\text { Financial } \\
\text { Institution } \\
\text { Participation }\end{array}$ & $\begin{array}{l}\text { An energy efficient project loan financing scheme of } \\
\text { RM } 16 \text { million has been setup at the Malaysian } \\
\text { Industrial Development Finance Bhd. (MIDF). As fund } \\
\text { managers, MIDF has disbursed loans for several } \\
\text { demonstration projects. The allocations are made } \\
\text { available by the Global Environment Facilities (GEF) } \\
\text { and the Malaysian Electric Supply Industry Trust } \\
\text { Account (MESITA) }\end{array}$ \\
\hline
\end{tabular}

Some of the deliverables of the programme were the following publications:

- Energy Efficiency and Conservation Guidelines

- Boiler Best Practices

- $\quad$ Energy Audit Guidelines

Among its successful projects were:

- Heveaboard saves up to RM720,000 on its annual bill from its wood dust fired thermal oil heater project $[8,10]$

- Cargill Palm Products saves more than RM1.9 million in energy costs

According to schedule, the project should have been completed by now. An evaluation report on the programme's effectiveness would provide a good review on how energy efficiency can be achieved in Malaysia's industries.

\section{The Environmental Objectives}

This objective was intended to minimize the negative impacts of energy production, transportation, conversion, utilization and consumption on the environment. All major energy development projects are subjected to the mandatory environmental impact assessment requirement outlined in the national environmental policies such as the National Policy on the Environment 2002. The environmental objective has strong pressure from the rapid energy demand growth in Malaysia.

Energy has strong environmental impacts at every level namely, exploitation of energy resources, energy supply and energy demand levels. Environmental consequences, such as emissions, discharges and noise, are subjected to the environmental quality standards such as air quality and emission standards. However, emission of pollutants to the atmosphere constitutes the biggest impact of the energy sector on the environment, the transportation industry being the biggest culprit [8].

As part of her efforts to fulfill this objective, Malaysia became a Party to the United Nations Framework on Climate Change in July 1994 and has ratified the Kyoto Protocol on 4 September 2002. The Kyoto Protocol was enforced on $16^{\text {th }}$ of February 2005. Malaysia has been following the negotiations and development of climate change issues very closely due to the numerous implications that could arise from the agreements achieved. As a developing country, Malaysia has no quantitative commitments under the Kyoto Protocol at present. However, through the Clean Development Mechanism (CDM), Malaysia could benefit from investments in the green house gasses (GHG) emission reduction projects, which will also contribute towards the country's sustainable development goals, the overall improvement of the environment and result in additional inwards financial flows [22].

CDM projects result in certified emission reductions (CERs) that could be traded in the international market. Like any other trade, these CER units accrued through the CDM are a commodity. These CERs would provide mutually shared benefits between developing and developed countries. The first applications for national CDM approval were received at the end of 2002. The energy related projects which are in the pipeline can be grouped into the following categories:-

- $\quad$ Energy Efficiency - to implement energy efficient improvements such as in an energy intensive factory

- Landfill Gas to Electricity - to utilize the methane in landfill gas for electricity production

- Renewable Energy - to utilize any biomass, biogas or hydropower for electricity generation [22]

\section{Other Implementation Efforts}

Besides the efforts in enabling the technological development in Malaysia, another commendable effort is the sharing of information to the public on the country's energy usage. This is done through several mechanisms such as: 
- Malaysia Energy Database and Information System (MEDIS) - to establish a comprehensive national database and information system to support an integrated national energy planning [23]

- Publications of periodic reports by the Energy Commission on the performance of the energy sector [7]

Another effort that has been implemented in conjunction with the National Energy Policy is the Integrated Resource Planning (IRP) project that attempts to take a comprehensive approach towards energy planning. The project was conducted in 2005 with the co-funding from the Danish International Development Agency (DANIDA). Three modeling tools Comparative Techno-Economic Assessment of Energy Supply, Energy Demand and Demand Side Management Option (COMPEED), Long Range Energy Alternatives Planning (LEAP) and Computable General Equilibrium (GCE) [24] were introduced. Energy planners and regulators were to evaluate the total costs and benefits of both the supply-side and demand-side options in energy planning. It enabled them to employ an optimal mix, which would provide energy at the least financial, social and environmental cost. These programs have enabled PTM to perform some integrated analyses, which were [9]:

\section{- Demand Side Management (DSM) analyses}

- Assessment of the combined heat and power (CHP)/ co-generation and

- Implementation of the Renewable Energy Power Generation Policy

The government also seems to portray its keenness on energy efficiency and renewable energy by example where their head offices are specially designed for green intent. These buildings are the low energy office of the Ministry of Energy, Green Technology and Water office in Putrajaya and the Zero Energy Office of PTM in Bandar Baru Bangi.

\section{FUTURE DIRECTIONS}

In April 2009, the Ministry of Energy, Water and Communications (MEWC) was replaced by the Ministry of Energy, Green Technology and Water. At the same time, the National Green Technology Policy was launched. Green technology refers to products, equipment or systems which satisfy the following criteria:

- Minimizes degradation of the environment

- Has a zero or low green house gas (GHG) emission

- $\quad$ Safe for use and promotes a healthy and improved environment for all forms of life

- Conserves the use of energy and natural resources

- Promotes the use of renewable resources [25].

This step can be interpreted as an affirmation of Malaysia's commitment towards sustainable development.
As the end of the Ninth Malaysia Plan is approaching in 2010 , it will be interesting to observe whether the $350 \mathrm{MW}$ target of RE will be achieved or not. It is also expected that the coming Malaysia plan will place more emphasis on energy efficiency and RE. A policy on nuclear energy is also in the midst of being drafted by the relevant ministries [26].

\section{CONCLUSIONS}

Malaysia has elaborate energy policies that govern her energy sector including its electricity industry. These have been supported by numerous implementation efforts. Beside the improvement in the country's electrification rate and supply quality and diversified electricity generation mix, the penetration of RE is yet to be proven. The end of the Ninth Malaysia Plan will provide a useful insight as to whether a more intensive approach towards RE and EE is required.

\section{ACKNOWLEDGMENT}

The authors wish to gratefully acknowledge the updated RE projects information provided by Sansubari Che Mud, Senior Manager, Renewable Energy Unit, Tenaga Nasional Berhad.

\section{REFERENCES}

[1] Tate, D.J.M.: 'Power Builds the Nation: the National Electricity Board of the States of Malaya and its predecessors' (1989. 1989)

[2] Ministry of Energy, Water and Communications.: 'National Energy Balance 2007',Pusat Tenaga Malaysia (National Energy Centre), 2007

[3] Tate, D.J.M.: 'Power Builds the Nation, the National Electricity Board of the States of Malaya and its Predecessors ' (1991. 1991)

[4] Tenaga Nasional Berhad webpage; http://www.tnb.com.my, accessed 20 February 2009

[5] Sarawak Electricity Company webpage: http://www.sesco.com.my, accessed 2 March 2009

[6] EC-ASEAN COGEN Programme (COGEN 3): 'National Energy Policy Review - Malaysia', Asian Institute of Technology (AIT), Thailand \& Carl Bro International, Sweden, 2003

[7] Energy Commission webpage: http://www.st.gov.myl, accessed 22 September 2009

[8] Ministry of Energy, Green Technology and Water webpage: http://www.kettha.gov.my/index.asp, accessed 22 September 2009

[9] Ministry of Energy, Water and Communications: 'Energy Policies of Malaysia', 2005

[10] Malaysia Energy Centre webpage: www.ptm.org.my, accessed 22 September 2009

[11] Economic Planning Unit (Malaysia): 'Seventh Malaysia Plan',1996, pp. 385-416

[12] Economic Planning Unit (Malaysia): 'Eighth Malaysia Plan', 2001, pp. 305-336

[13] Economic Planning Unit (Malaysia): 'Ninth Malaysia Plan', 2006, pp. $393-410$

[14] Economic Planning Unit: 'Fifth Malaysia Plan',1986

[15] The Star, 20 September 2008, Singh, S.: 'Malaysia to use nuclear energy by 2023 ', 2008

[16] Osman, Z.: 'Renewable Energy Development in Malaysia', Universiti Tenaga Nasional, 2006

[17] Economic Planning Unit: 'Eighth Malaysia Plan Midterm Review', 2003, pp. 239-273

[18] Biogen programme webpage: http://www.ptm.org.my/biogen/, accessed 23 September 2009

[19] Dahlen, B.F.: 'Hydro Power in Malaysia' (Tenaga Nasional Berhad, 1993. 
[20] Evald, A.: 'Renewable Energy Resources ', 2005

[21] MBIPV programme webpage: http://www.mbipv.net.myl, accessed 23 September 2009

[22] CDM webpage: http://cdm.eib.org.my/index.php, accessed 23 September 2009

[23] MEDIS webpage: http://medis.ptm.org.myl, accessed 23 September 2009
[24] Blarke, M.: 'Integrated Resource Planning: General Methodology and Assumptions', Economic Planning Unit, 2005

[25] Ministry of Energy, Green Technology and Water: 'National Green Technology Policy', 2009

[26] Global Times, 9 July 2009, Xinhua: 'Malaysia to draft nuclear energy policy', 2009 